\title{
Proposed supply chain risk mitigation strategy of chicken slaughter house PT $X$ by house of risk method
}

\author{
Maria Ulfah ${ }^{1}$, Dyah Lintang Trenggonowati ${ }^{1}$, and Fadila Zahra Yasmin ${ }^{1}$ \\ ${ }^{1}$ Departement of Industrial Engineering, Faculty of Engineering, University of Sultan Ageng \\ Tirtayasa, Banten, Indonesia
}

\begin{abstract}
Slaughter House PT X is a company engaged in the production, trade, and distribution of chicken meat that having a role to provide the needs of raw material in a form of fresh chicken meat in the chicken meat processing industry. However, this company has the potential to experience a variety of supply chain risk that can disrupt the company's business processes. The purposes of this study are to identify risk events that have been potentially occurred, identify priority risk agent based on Aggregate Risk Potential (ARP) value, and determine the priority sequence of a risk mitigation strategy in Slaughter House PT X. This study uses the Supply Chain Operation Reference (SCOR) to mapping the company's supply chain activity. Thereafter House of Risk (HOR) method is used to identify, analyze, evaluate, and designing mitigation strategy to minimize potential occurrence of risk agent. The results of the study showed that there are 33 risk events and 32 risk agents identified. Then, based on the result of risk evaluation, there are 15 priority risk agents for mitigation action. There are 11 proposed mitigation strategies to be implemented in Slaughter House PT X.
\end{abstract}

\section{Introduction}

Supply chain management is not a new thing for the company nowadays. The company should have to manage and run the supply chain to fulfill customer needs [1]. The complexity of multiple stakeholder within the supply chain structure and the number of uncertainties poses challenge in supply chain management.

The emergence of risks in supply chain activity becomes unavoidable. To reduce and overcome the various risks that occurred within the supply chain, it will be required to undertake a continuous improvement of supply chain performance by overcoming and preventing various risks which potentially occurred [2]. Supply chain risk management becomes an effort to manage the risks that have been occurring along the supply chain flow.

Chicken slaughter house PT $\mathrm{X}$ is a company engaged in production, trade, and distribution of chicken meat to fulfill the needs of raw materials in the form of fresh

${ }^{1}$ Corresponding author: maria67_ulfah@yahoo.com 
chicken meat for chicken meat processed industry or sold directly to customers through the retailer. The complexity within agro industry supply chain can caused some problem on its supply chain flow. The problems that occurred in chicken slaughter house PT X are based on the monthly report data of production result in 2016 and 2017, showed unstable production results for every month in a year also there are several months that cannot fulfill the production target. Furthermore, there was a decreased value of the yield percentage of the total net weight of life bird as a raw material to the total net weight of finished product in the form of chicken meat where the yield value of 2016 is $75,19 \%$ decreased to $74,37 \%$ in 2017. The causes of these problems are variable, it is not only came from the company, but also from the farm in the form of life bird as the supplier. If there is a risk in the supplier as an upstream supply chain, it will affect the customer as a downstream in the supply chain. Therefore, supply chain risk management in PT X is required to reduce or even eliminate potential risks in the company's supply chain activity.

The goals of the research are to identify risk events that potentially occurred within the business process in chicken slaughter house PT X, identify priority risk agents based on Aggregate Risk Potential (ARP) value that causes the risk to occur within a business process in chicken slaughter house PT X and determine the priority sequence of applying proposed risk mitigation based on Effectiveness to Difficulty Ratio (ETD) value on chicken slaughter house PT X.

\section{Research method}

House of Risk (HOR) is formed from modification of FMEA (Failure Modes and Effect Analysis) and House of Quality (HOQ) model to prioritize which risk agent that selected first to take the most effective action in order to reduce the risk potential of risk agent.

There are two phases used in House of Risk (HOR) approach that is HOR 1 which is used to determine the priority level of risk agent that supposed to give a preventive action and HOR 2 that used to determine priority in taking effective action [3].

The steps of House of Risk (HOR) first phase are [2]:

1. Identify the risk event that may occur in every business process.

2. Estimate the impact of some risk events (if they have occurred).

3. Identify the risk agent and asses the probability of risk occurrence for each risk agent.

4. Develop the linkage matrix relationship between each risk agent and risk event.

5. Calculate the Aggregate Risk Potential of agent $\mathrm{j}\left(\mathrm{ARP}_{\mathrm{j}}\right)$ value.

$$
A R P_{j}=O_{j} \Sigma S_{i} R_{i j}
$$

$\mathrm{ARP}_{\mathrm{j}}=$ Aggregate Risk Potential of Risk agent $\mathrm{j}$

$\mathrm{O}_{\mathrm{j}} \quad=$ Occurrence value

$\mathrm{S}_{\mathrm{i}} \quad=$ Severity value

$\mathrm{R}_{\mathrm{ij}} \quad=$ Correlation value between risk event $\mathrm{i}$ and risk agent $\mathrm{j}$

$\mathrm{R}_{\mathrm{ij}} \in\{0,1,3,9\}$

6. Rank the risk agent based on aggregate risk potential value in decreasing order (from highest to lowest).

The steps of House of Risk (HOR) second phase are [2]:

1. Select a number of risk agents with highest priority rank using Pareto analysis of $\mathrm{ARP}_{\mathrm{j}}$ value, declare in the second phase of House of Risk (HOR).

2. Identify relevant action that considered to prevent the risk agent or Proactive Action (PA).

3. Determine the relationship between each risk agent and proactive action, $\mathrm{E}_{\mathrm{jk}}$. 
4. Calculate the Total Effectiveness value for each action as follows [2]:

$$
T E_{k}=\Sigma_{j} A R P_{j} E_{j k} f
$$

TEk $=$ Total Effectiveness

$\mathrm{ARPj}=\mathrm{ARP}$ value

Ejkf = correlation value of risk agent and mitigation action

5. Estimate the degree of difficulty in performing each action, Dk. Calculate the effectiveness to difficulty ratio.

ETD $=$ Effectiveness to Difficulty

$$
E T D_{k}=\frac{T E_{k}}{D_{k}}
$$

$\mathrm{Dk}=$ degree of difficulty

6. Rank the priority of each action (Rk) which means first rank is the action with highest ETD value.

This is the figure 1 of flowchart in this research.

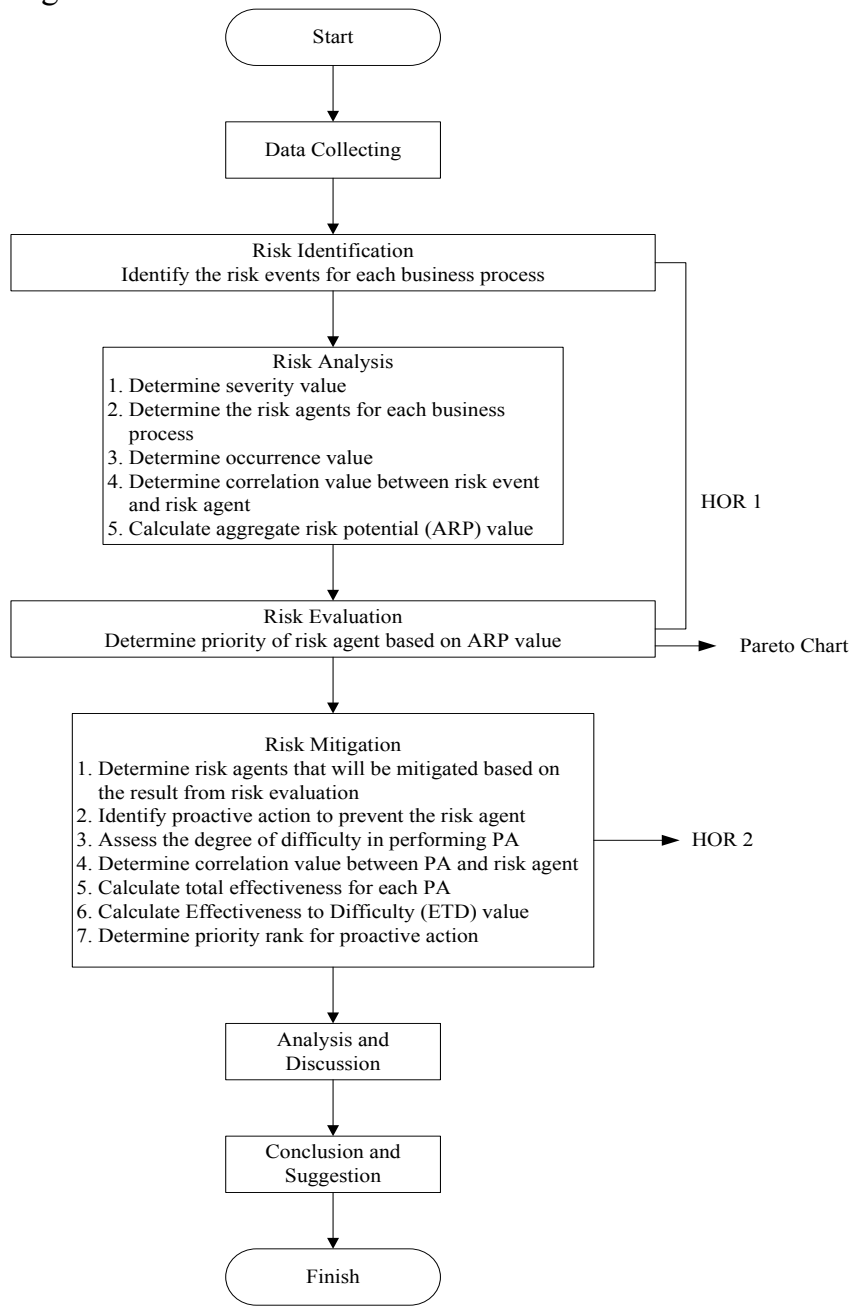

Fig 1 Research flowchart 


\section{Result and discussion}

Data processing in this study consist of risk identification, risk analysis, and risk evaluation that belong to House of Risk first phase, and risk mitigation that belongs to House of Risk second phase.

\subsection{Risk identification}

Risk identification is an early stage for the study using House of Risk (HOR) method in the first phase. In this stage, the risk identification performed by the mapping of supply chain activity that has been identified previously using the Supply Chain Operation Reference (SCOR) method. The risk that has been identified either unprecedented or have a probability to occur in the supply chain activity of chicken slaughter house PT X. There are 33 risk events identified in the supply chain on chicken slaughter house PT X.

\subsection{Risk analysis}

The next stage is risk analysis.

Table 1 Risk agent assessment

\begin{tabular}{clc}
\hline Code & \multicolumn{1}{c}{ Risk Agent } & Occurrence (O) \\
\hline A1 & Inappropriate product demand planning & 5 \\
A2 & Fluctuating market condition & 9 \\
A3 & Lack of raw materials needed & 7 \\
A4 & Unexpectedly product demand from & 9 \\
customer & 5 \\
A5 & Inappropriate raw material planning & 6 \\
A6 & The farm does not provide the required & chicken size \\
& Insufficient ordering of live chicken's & 5 \\
A7 & quantity that comply the specification & \\
A8 & External factors (currency exchange rate, & 3 \\
& government policy) & \\
A9 & Delay in support material procurement & 6 \\
& from packaging warehouse & 6 \\
A10 & Nature disaster & 3 \\
A11 & Inaccurate inspection of raw material & receipts \\
A12 & Variation size of live chicken weight & 7 \\
A13 & Delay of raw material & 7 \\
A14 & Disrupted power supply & 2 \\
A15 & Machine downtime & 8 \\
A16 & Lack of machine maintenance & 7 \\
A17 & Inaccurate operator & 7 \\
A18 & Error during packing pressing process & 4
\end{tabular}

\begin{tabular}{lll} 
A19 & $\begin{array}{l}\text { Error during final weighing of finished } \\
\text { product }\end{array}$ & 4 \\
A20 & Error printing on the packaging & 4 \\
A21 & Imperfect defeathering process & 3 \\
A22 & Bacterial contamination & 2 \\
A23 & Unhygenic production process & 1 \\
A24 & $\begin{array}{l}\text { Inaccurate physical checking of finished } \\
\text { product }\end{array}$ & 2 \\
A25 & $\begin{array}{l}\text { Inappropriate water temperature on drum } \\
\text { chiller process }\end{array}$ & 1 \\
A26 & $\begin{array}{l}\text { Lack of coordination between shipping } \\
\text { departement and warehouse departement }\end{array}$ & 5 \\
A27 & $\begin{array}{l}\text { Error while order recording } \\
\text { A28 }\end{array}$ & $\begin{array}{l}\text { No transport truck } \\
\text { Lack of communication with sales }\end{array}$ \\
A29 & $\begin{array}{l}\text { departement } \\
\text { Inappropriate coolant temperature in the } \\
\text { truck }\end{array}$ & 5 \\
A30 & 2 \\
A31 & $\begin{array}{l}\text { Lack of coordination with warehouse } \\
\text { departement }\end{array}$ \\
A32 & $\begin{array}{l}\text { Delay of the transporter to take retur } \\
\text { product }\end{array}$ & 5 \\
\hline
\end{tabular}

Based on table 1 above, the process of risk agent identification has been obtained 32 risk agent in the supply chain of chicken slaughter house PT X. Risk agent with rating 8 (high) or frequent is a machine downtime (A15), this is caused by frequent component replacement. Risk agent with rating 9 and 10 (very high) or hard to avoid, first is fluctuating market condition (A2), this is often occurring because of the increasing or decreasing the need of chicken meat in some certain period in a year. The second is unexpectedly product demand from customers (A4), this is often occurring because of the customer wants to increase their production result, so that they need to add the order beyond initial order.

\subsection{Risk evaluation}

Risk evaluation is the stage to determine priority sequence of risk agent that will be mitigated based on Aggregate Risk Potential (ARP) value. ARP value is used as a reference and input to determine the priority of which risk agent that should be handled first by sorting the ARP value from the largest to the smallest to analyze using Pareto chart [4]. 
Aggregate Risk Potential (ARP) is the result of multiplication of occurrence value with sigma of the result of multiplication of severity value with correlation value. ARP value is determinant of how much the risk affects chicken slaughter house PT X. The greater ARP value in a risk agent, the more harmful and dangerous the risk is, it means supposed to take the action immediately [5].

Based on the result of risk agent prioritization, there are 15 risk agents that have been obtained belong to priority risk agent and 17 risk agents belong to non-priority risk agent.

The risk agents belong to a priority risk agents are A4, A15, A16, A17, A2, A6, A7, $\mathrm{A} 12, \mathrm{~A} 9, \mathrm{~A} 28, \mathrm{~A} 19, \mathrm{~A} 3, \mathrm{~A} 13, \mathrm{~A} 27$, and $\mathrm{A} 5$, whereas the risk agents belong to non-priority risk agents are A26, A10, A29, A1, A31, A18, A20, A11, A21, A22, A32, A23, A14, A30, A8, A25, and A24. This in table 2 of the result of Aggregate Risk Potential (ARP) value.

Table 2 Aggregate Risk Potential (ARP) calculation

\begin{tabular}{|c|c|c|c|c|c|c|}
\hline Code & Risk Agent & ARP & \%ARP & \%Cum ARP & Rank & Category \\
\hline A4 & $\begin{array}{l}\text { Unexpectedly product demand from } \\
\text { customer }\end{array}$ & 2133 & 11,818 & 11,818 & 1 & \multirow{15}{*}{$\begin{array}{c}\text { Priority } \\
\text { Risk } \\
\text { Agent } \\
\text { (A) }\end{array}$} \\
\hline A15 & Machine downtime & 1656 & 9,176 & 20,994 & 2 & \\
\hline A16 & Lack of machine maintenance & 1575 & 8,727 & 29,721 & 3 & \\
\hline A17 & Inaccurate operator & 1554 & 8,610 & 38,331 & 4 & \\
\hline A2 & Fluctuating market condition & 1458 & 8,078 & 46,410 & 5 & \\
\hline A6 & $\begin{array}{l}\text { The farm does not provide the required } \\
\text { chicken size }\end{array}$ & 1188 & 6,582 & 52,992 & 6 & \\
\hline A7 & $\begin{array}{l}\text { Insufficient ordering of life bird's quantity } \\
\text { that comply the specification }\end{array}$ & 720 & 3,989 & 56,981 & 7 & \\
\hline $\mathrm{A} 12$ & Variation size of life bird weight & 672 & 3,723 & 60,705 & 8 & \\
\hline A9 & $\begin{array}{l}\text { Delay in support material procurement } \\
\text { from packaging warehouse }\end{array}$ & 648 & 3,590 & 64,295 & 9 & \\
\hline A28 & No transport truck & 630 & 3,491 & 67,786 & 10 & \\
\hline A19 & $\begin{array}{l}\text { Error during final weighing of finished } \\
\text { product }\end{array}$ & 504 & 2,793 & 70,578 & 11 & \\
\hline $\mathrm{A} 3$ & Lack of raw materials needed & 441 & 2,443 & 73,022 & 12 & \\
\hline A13 & Delay of raw material & 441 & 2,443 & 75,465 & 13 & \\
\hline $\mathrm{A} 27$ & Delay of raw material & 432 & 2,394 & 77,859 & 14 & \\
\hline A5 & Inappropriate raw material planning & 360 & 1,995 & 79,854 & 15 & \\
\hline
\end{tabular}

The following is fig 2 of the Pareto chart to determine the priority risk agent to be mitigated.

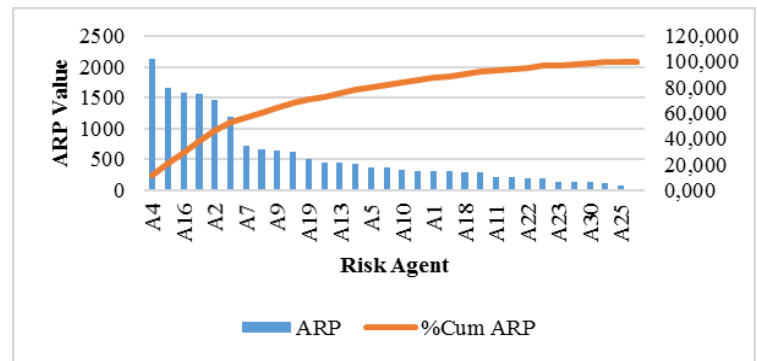

Fig 2 Pareto chart of risk agent 
The priority risk agent is obtained from 79,854\% (80\%) total of cumulative ARP, while the non-priority risk agent is derived from remaining $20 \%$ of cumulative ARP. Intake of $80 \%$ from total cumulative ARP based on $80: 20$ Pareto chart principle, which is $20 \%$ of total risk agent contribute about $80 \%$ of total cumulative ARP [4].

\subsection{Risk mitigation}

Risk mitigation includes the activity to manage and monitor risk, create mitigation measures, reduce risk impact, and reduce the likelihood of occurrence. The proposed mitigation strategy was proposed by researcher then discussed with expert judgement in chicken slaughter house PT X. Based on 15 priority risk agent as the result of House of Risk (HOR) first phase, there are 11 mitigation strategy to prevent risk occurring in the supply chain.

Then performed the assessment for degree of difficulty to implementing each proposed mitigation strategy for the company. The next step is calculating Total Effectiveness (TEk) value for each mitigation strategy. TEk value that has calculated can not represent how proper these precautions can effectively fix some risk. Therefore, it is necessary to calculate Effectiveness to Difficulty Ratio (ETD) value for each mitigation strategy. ETD value can represent the level of effectiveness of mitigation strategy to be realized and fixed the risk. ETD value is needed to determine the priority sequence of mitigation strategy by sorting the value from the highest to the lowest [6].

Prioritizing the implementation of mitigation strategy is to determine alternative risk mitigation assessment that can be implemented by concerned the limitation of cost, human resources, and other aspects of the company [6].

Table 3 Priority of Risk Mitigation Strategy

\begin{tabular}{clc}
\hline Code & \multicolumn{1}{c}{ Proactive Action } & Rank \\
\hline PA2 & Performing reliability maintenance & 1 \\
PA3 & $\begin{array}{l}\text { Conduct regular training for workers } \\
\text { Promotes implementation of work }\end{array}$ & 2 \\
PA8 & $\begin{array}{l}\text { instruction } \\
\text { PA4 }\end{array}$ & Intensive market research \\
PA11 & Forecasting and collaborative planning & 5 \\
PA9 & $\begin{array}{l}\text { Perform evaluation supplier } \\
\text { performance of live chicken suppliers }\end{array}$ & 6 \\
PA10 & $\begin{array}{l}\text { Improve communication and } \\
\text { coordination with customers }\end{array}$ & 7 \\
PA6 & $\begin{array}{l}\text { Looking for alternative suppliers for } \\
\text { live chicken }\end{array}$ & 8 \\
PA1 & $\begin{array}{l}\text { Set up buffer stock } \\
\text { PA5 }\end{array}$ & $\begin{array}{l}\text { Selective supplier of live chicken } \\
\text { selection }\end{array}$ \\
PA7 & $\begin{array}{l}\text { Improve coordination with the } \\
\text { shipping company }\end{array}$ & 9 \\
\hline
\end{tabular}

\section{Conclusion}

Based on the research result and analysis, it can be concluded that: 
1. There are 33 risk events that potentially arise in the business process chicken slaughter house PT X among others are error in determining the needs of live chicken, required size of live chicken is unavailable, the farm cannot fulfill the order, live chicken size that has been received is inappropriate, and shackle rail plummeted.

2. There are 15 priority risk agents based on Aggregate Risk Potential (ARP) value belong to risk agent A category. Risk agent sequence based on Aggregate Risk Potential (ARP) value is unexpectedly product demand from customer (A4) with ARP value is 2133, machine downtime (A15) with ARP value is 1656, lack of machine maintenance (A16) with ARP value is 1575, inaccurate operator (A17) with ARP value is 1554, and fluctuating market condition (A2) with ARP value is 1458 .

3. The sequence of priority of proposed mitigation strategy to be implemented based on Effectiveness to Difficulty Ratio (ETD) value in chicken slaughter house PT X are performing reliability maintenance (PA2), conduct regular training for workers (PA3), promotes implementation of work instruction (PA8), intensive market research (PA4), forecasting and collaborative planning (PA11), perform evaluation supplier performance of live chicken suppliers (PA9), improve communication and coordination with customers (PA10), looking for alternative suppliers for live chicken (PA6), set up buffer stock (PA1), selective supplier of live chicken selection (PA5), and improve coordination with the shipping company (PA7).

\section{Reference}

1. Utari, R. dan Baihaqi, I. Perancangan Strategi Mitigasi Resiko Supply Chain di PT Atlas Copco Nusantara dengan Metoda House of Risk. B-19-2. (2015)

2. Ulfah, M. Maarif, M. S. Sukardi. Raharja, S. Analisis dan Perbaikan Manajemen Risiko Rantai Pasok Gula Rafinasi dengan Pendekatan House of Risk. 26 (1), 87-103. (2016)

3. Pertiwi, Y. E. Susanty, A. Analisis Strategi Mitigasi Resiko pada Supply Chain V Surya CIP dengan House of Risk Model. Vol 6 No 1, 2. (2017)

4. Nugraheni, S. A. Yuniarti, R. Sari, R. A. The Analysis of Supply Chain Risk on Ready To Drink (RTD) Product using House of Risk Method. Vol 5 No 1, 49. (2017)

5. Arafiany, N. M. Usulan Aksi Mitigasi Risiko Rantai Pasok Pabrik Baja Lembaran Dingin PT XYZ Menggunakan Metode House of Risk (HOR). 144. (2017)

6. Elvandra, A. R. Maarif, M. S. Sukardi. Management of Supply Chain Risk in Cattle Slice Fattening at PT Catur Mitra Taruma.. Vol 4 No 1, 97. (2018) 